\title{
НОВО ИЗСЛЕДВАНЕ ЗА РУСКОТО УЧАСТИЕ В ДЕВЕТОЮНСКИЯ ПРЕВРАТ 1923 Г.
}

\author{
Бисер Георгиев \\ A NEW STUDY ON RUSSIAN PARTICIPATION \\ IN THE JUNE COUP, 1923 \\ Biser Georgiev
}

(Козодой, В. И. Белый реванш в стране алых роз. Александр Гучков и государственный переворот 9 июня 1923 года в Болгарии. Новосибирск: СГУГиТ, 2019)

DOI: https://doi.org/10.46687/BLAU5861

През есента на 2019 г. в Новосибирск, Русия, излезе от печат монографията на известния руски учен, доктор на историческите науки Виктор Иванович Козодой. Тя е посветена на част от биографията на руския държавник Александър Иванович Гучков ${ }^{1}$, като до голяма степен засяга неговата дейност в България през периода 1921 - 1923 г. Това е времето, когато в страната се намира значителна част от разбитата Врангелова армия. Козодой проследява нейното участие в заговорите и преврата срещу правителството на Ал. Стамболийски.

\footnotetext{
${ }^{1}$ Александър Ив. Гучков е руски политик и държавник, водач на партията „Съюз 17 октомври" - дясно ориентирана конституционно-либерална политическа организация на едрите земеделци, промишленици и чиновници, просъществувала от 1905 до 1917 г. Името ѝ е свързано с изпратения до император Николай II манифест на посочената дата през 1905 г. (Politicheskie partii Rossii 2000: 631). Гучков е председател на Третата държавна Дума (1910 - 1911 г.), член на Държавния съвет на Руската империя (институция със законодателни функции в периода 1906-1917 г., вж. Alekseeva 2005: 182-281), председател на Централния военно-промишлен комитет (1915 - 1917 г.) и военен министър във Временното правителство на княз Г. Лвов (март - май 1917 г.). Като монархист по убеждение се опитва да наложи с преврат смяната на Николай II със сина му Алексей, но не успява. По време на Гражданската война в Русия е преследван от болшевиките и се укрива в гр. Кисловодск. Впоследствие се добира до Екатеринодар и предоставя услугите си на ген. А. Деникин. Последният го изпраща през 1919 г. като свой парламентьор в Западна Европа. Оттам нататък, до смъртта му през февруари 1936 г., животьт му преминава в емиграция с планове за сваляне на правителството в Съветска Русия (след 1924 г. - СССР).
} 


\section{Годишник на ФХH, XXXII A}

Безспорно руският поглед върху българските събития от пролетта и лятото на 1923 г. е изключително важен, защото в историческата наука все още съществуват спорове за характера на преврата, за участието на отделните политически сили в него и пр. (Nedev 1984; Nedev 2007; Georgiev 1989; Naumov 2004; Vasilev 1991; Spasov 1977; Spasov 1979 /1/; Spasov 1979 /2/; Spasov 1999; Mitev 1973; Petrova 1988 и мн. др.). Към това следва да прибавим новоизвлечения непубликуван изворов материал от Руския държавен архив (ГАР $\left.{ }^{2}\right)$, от Руския държавен архив за социалнополитическа история (РГАСПИ ${ }^{3}$ и от Централния държавен архив в София, който авторьт представя. Пуснати са в научно обращение много нови източници от руския периодичен печат, включително белогвардейски издания в Берлин (1920 - 1923 г.), в Рига (1920 - 1923 г.) и в София (1921 - 1923 г.). Обърнато е съществено внимание на мемоарната литература предимно на руски език.

Представеният научен труд на Виктор Козодой открива нова тематика за автора, който в общи линии до този момент се занимава с посъвременни теми (Kozodoy 2004; Kozodoy 2009; Kozodoy 2011; Kozodoy et al. 2018 и др.). Той обаче е продължение на други негови публикации за живота и дейността на слабо познатия на българските историци Ал. Ив. Гучков (Kozodoy 2014: 121-128; Kozodoy 2015; Kozodoy 2017: 283290).

Монографията на Козодой прави сериозен опит да отговори на важния въпрос в българската история каква е ролята на врангелистите в преврата срещу правителството на Ал. Стамболийски на 9 юни 1923 г. Подробното представяне на дейността на Ал. Гучков, който стои в основата на някои от плановете и преговорите с българските опозиционни на БЗНС сили, го определя като опитен познавач на политическата технология и изключителен организатор. През 1911 г., по време на престоя си в Китай, Гучков предсказва революцията там и ролята на обществените организации в нея. Той е един от малкото руски политици, които виждат в пресата не само средство за осведомяване, но и „информационно оръжие” за борба с противниците. В изпълнение на тази концепция през 1898 г. като офицер на служба в КВЖД ${ }^{4}$ основава първото рускоезично списание в Китай „Харбин”. Дьлгогодишният му

\footnotetext{
${ }^{2}$ Государственный архив Российской Федерации.

${ }^{3}$ Российской государственный архив социально-политической истории.

${ }^{4}$ Китайско-Восточная железная дорога.
} 
опит по-нататьк го убеждава, че „пресата контролира общественото мнение".

Връзката на Ал. Гучков с България, както сочи авторът В. Козодой, датира още от началото на XX век. През 1903 г. по време на Илинденското въстание той отлага сватбата си и заминава за Македония. От 8 до 14 август посещава София, Смилево и Рилския манастир, а после за втори път се връща в българската столица, откъдето на 21 август отпътува за Русия. По време на престоя си се запознава с дейци от македонските революционни организации - важен фактор в преврата през 1923 г.

Второто посещение на Гучков в България е през 1910 г. Като председател на Дьржавната дума на Русия той е избран за водач на руската делегация на Втория славянски събор в София. Посещава и Варна, а по време на визитата си се запознава с А. Ляпчев, Ив. Ев. Гешов, Ст. С. Бобчев, д-р Ст. Данев и други български политици русофили.

За трети път руският държавник идва в България през 1912 г., като се изказва песимистично за бъдещите събития на Балканите.

След Първата световна война Ал. Стамболийски управлява в сложна обстановка, известен фактор за която е влиянието на Бялата армия на ген. П. Врангел, приета на българска територия. В. Ив. Козодой публикува важно писмо на Гучков до ген. Врангел от 25 декември 1922 г., в което е описан подробно планът и ролята му за преврата в България. Подателят определя точно мястото и значението на руската политическа емиграция и на армията на Врангел в политическия преврат на фона на вътрешната и външнополитическата обстановка в България през периода 1920 - 1923 г. и ситуацията в Русия от 1917 до 1923 г.

За да се справи със задачата, която си е поставил, авторьт на монографията проследява еволюцията в отношенията между Бялата армия и правителството на Стамболийски, както и противоречията между офицерите на Врангел и агентите на Съветска Русия, действащи на територията на България. Според Козодой това е продължение на Руската гражданска война, но с други средства - информационни, когнитивни и физическа саморазправа. За обществеността в България и в Европа превратьт е „неочакван”, но за белогвардейците това е „реваншът”, който те постигат срещу „червените” за поражението в Крим през 1920 г. Оценката на Ал. Гучков в цитирано писмо до Врангел от 10 юни 1923 г. е недвусмислена: „Случи се неизбежното <..> За мен това беше ясно като Божи ден”. В него се споменава също, че превратът е извършен 


\section{Годишник на ФХH, XXXII A}

съвместно с дясната българска опозиция. В защита на своята теза авторът представя доказателства и от българския периодичен печат и архиви.

Разбира се, подобна крайна теза би могла да бъде оспорена от други изследвачи на периода, но в случая е по-важно, че направената публикация (Kozodoy 2019) ${ }^{5}$ предизвиква сериозна дискусия и дава основание за нови изследвания по посочената тема. Заслужава сериозно внимание и предговорът на проф. Л. Спасов, който в общи линии представя и коментира основни тези на труда.

Едно от достойнствата на монографията е подробното проследяване на еволюцията в отношенията на правителството на БЗНС с белогвардейската емиграция, чиято численост постепенно нараства до 60000 души, от които 21000 са бивши военни, запазили оръжието си ${ }^{6}$. В. Козодой сочи, че под натиска на Франция Ал. Стамболийски сключва договор с ген. Шатилов, командващ Врангеловата армия на българска територия, и допуска смесването на местното население с белогвардейците. Правителството създава и административен пост комисар по въпросите на руските бежанци, който поверява на бъдещия екзарх Стефан I ${ }^{7}$. С решение на Министерството на външните работи през ноември 1921 г. е създаден и Руско-български комитет, ръководен отново от епископ Стефан. Връх на доброто отношение към белогвардейците стават личната среща на Стамболийски с представители на руската общественост на 17 декември 1921 г., както и изключително тържественото посрещане във Варна на последния руски ешелон начело с ген. Александър Кутепов ${ }^{8}$. Срещу тези действия на земеделците протестират вестниците на българските комунисти, докато част от дясната, главно русофилски настроена опозиция, ги подкрепя. Известни политици като Ив. Ев. Гешов, Т. Теодоров и Вл. Моллов организират вечеринки и събират помощи за руските бежанци.

\footnotetext{
${ }^{5}$ В началото на 2020 г. книгата беше отпечатана и на български език, но на някои места преводът се различава в нюансите от оригинала.

6 Авторьт на монографията изнася сведения, че белогвардейците разполагат с 21600 винтовки, 7800 саби, 55 автомобила и пр.

7 По това време Стоян Попгеоргиев Шоков все още не е глава на българската православна църква. През 1921 г. той е ръкоположен за Маркианополски епископ, а рькополагането му за Софийски митрополит става едва през 1922 г. За живота му вж. Pendzhekova 2007. Разбира се, посочената дребна забележка не намалява достойнствата на монографията на В. Ив. Козодой.

${ }^{8}$ На него присъстват Варненският митрополит, варненският градоначалник и е връчен адрес от името на 24 организации.
} 
В. Ив. Козодой представя началото на охлаждането на отношенията между БЗНС и белогвардейците под влияние на промените в международната обстановка, но вътрешнополитическите събития в България са не по-малко важни. Наистина, на Генуезката конференция (април - май 1922 г.) британският министьр-председател Дейвид Лойд Джордж се изказва в подкрепа на признаването на Съветска Русия9 ${ }^{9}$. След срещата в Генуа между Кр. Раковски - рьководител на Украинската съветска република, и Ал. Стамболийски, последният праща указания за мощна кампания срещу руския контингент, но промяната на отношението на българските управляващи към белогвардейците започва по-рано. На пиянски скандал в Свищов руски военни си позволяват да „накажат” български офицер, което става повод правителството да определи като краен срок за разоръжаването на врангеловите части 15 март 1922 г. От това се възползва дясната опозиция. По случай 3 март в Търново Народно-прогресивната партия организира банкет в чест на ген. Кутепов. Подобни мероприятия се провеждат в Орхание (дн. Ботевград, б. а. Б. Г.), Кюстендил и Сухиндол, а в Стара Загора реч в защита на белогвардейците произнася лично д-р Ст. Данев. В отговор българските комунисти провеждат мащабни акции за разоръжаване на врангелистите. Както сочи сам авторьт на монографията, от пролетта на 1922 г. българската преса, в лицето на земеделците и комунистите, започва да напада ген. Врангел и остатъците от неговата армия в България. Създаден е и „Совнарод” (Съюз за връщане на емигрантите в Русия. За него Вж. Spasov 1987: 87-99). Врангелистите отговарят на нападките чрез руския емигрантски вестник „Свободна реч”, но тезата на Козодой, че в България се води „информационна война” срещу правителството на БЗНС трудно би могла да бъде приета. Авторьт свързва тази своя теория с общото разбиране на Гучков за ролята на пресата в обществото, на която се спряхме по-горе, но следва да посочим, че до този момент, а и след него, ожесточените вестникарски атаки са често срещано явление в българските политически условия. Като пример можем да посочим времето на управлението на Народната партия (1894 - 1899 г.), самостоятелното управление на радославистите (1899 - 1900 г.) и второто самостоятелно управление на народнолибералите (1903 - 1908 г.), когато вестникарската война в много отношения е подобна на тази от 1920 - 1923

${ }^{9}$ Срещу емигрантите е и подписаният в Рапало, Италия, на 16 април 1922 г. договор между Германия и Съветска Русия, който силно впечатлява Ал. Стамболийски. 


\section{Годишник на ФХH, XXXII A}

г. (Вж. напр. Georgiev 2014: 347-360; Georgiev 2020: 235-254; Georgiev 2018: 167-198).

Формално Врангел, който се намира в Сърбия и идва в България само инцидентно, дава заповед на армията си да не взема участие в политически събития, но през май 1922 г. е арестуван началникът на неговото контраразузнаване полк. П. Самохвалов, заедно с 10 тома архив, карти на стратегически места в България, писма до главнокомандващия, до ген. Кутепов и пр. Това дава повод на „Работнически вестник” да развие тезата за подготвян държавен преврат заедно с десните опозиционни партии. Във вестник „Земеделско знаме” пък министърът на търговията, промишлеността и труда Александър Радолов ${ }^{10}$ обявява, че врангелистите, „партийният блок”11, Офицерската лига и „четниците” (ВМРО) ще се обединят, за да свалят БЗНС от власт.

В. Козодой описва подробно случилото се през пролетта и лятото на 1922 г. В резултат от възникналото напрежение на 15 май ген. Ал. Кутепов е принуден да напусне страната и с това руската военна мисия в България е ликвидирана. Изгонени са 95 руски офицери и са арестувани 263 руски граждани. Предприети са обиски за изземване на оръжие. Положението на остатъците от Врангеловата армия на българска територия се утежнява особено много към края на 1922 г., с което Козодой обяснява плана на Гучков за преврат, изложен в писмо до ген. П. Врангел. Последният възлага военно-техническата подготовка на ген. С. Ронжин и ген. Николский, които я извършват заедно с българските генерали Ив. Вълков и Ив. Русев. По-късно в съзаклятието са посветени проф. Ал. Цанков и други дейци от българската опозиция. Голяма част от тях, според В. Козодой, не подозират за участието на руските генерали в заговора. Последното обаче намалява аргументациите за тезата, че превратът на 9 юни до голяма степен е руско дело. Търсенето на руско участие при разработката на идеите и планирането във военнотехническо, дипломатическо и информационно направление е правилно, но то не доказва автоматично теорията за „реванш” и продължаване на Гражданската война. Една от причините за това е обстоятелството, че многократно, според Козодой, предупреждавания за заговора Ал.

\footnotetext{
${ }^{10}$ От 21 ноември 1921 до 5 януари 1922 г. той за кратко е министьр на вътрешните работи - Balgarskite darzhavni institutsii 1986: 320-321.

${ }^{11}$ Става въпрос за сформирания на 6 юли 1922 г. Конституционен блок, който авторът донякъде смесва с Народния сговор. В него влизат Демократическата, Народнопрогресивната и Радикалната партия (Todorov 2018: 319-320 и цит. лит).
} 
Стамболийски и близките му сподвижници не са позитивно настроени към болшевиките. В условията на почти пълна международна и особено балканска изолация те са принудени да лавират, без да могат да постигнат съществени външнополитически резултати. Не можем например да подминем обстоятелството, че под влияние на западноевропейските велики сили руско-българските дипломатически отношения не са възстановени и влиянието на болшевиките върху българския политически живот се ограничава почти единствено до контактите им с БКП т. с. посредством Комунистическия интернационал.

Не можем да изключим наличието на сериозни обективни предпоставки за евентуално фактическо белогвардейско участие в преврата. Факт е, че поради Ньойския договор през посочения период българската армия наброява по-малко от 20000 души $^{12}$, което прави макар и леко въоръжената Врангелова армия сериозна военна сила. Не е за подценяване също обстоятелството, че Париж и Лондон, поне в началните години след Пьрвата световна война, оказват активна подкрепа на белогвардейците. С течение на времето обаче политическите реалности надделяват и възможностите за пълен обрат на ситуацията във вече Съветска Русия стават илюзорни. Идеите за реванш остават единствено в мислите на по-изявените бивши държавници и висши военни, въпреки че вероятно и те осъзнават невъзвръщаемостта на случилото се. В тази връзка участието на белогвардейците в преврата срещу правителството на БЗНС следва да се разглежда по-скоро като помощ по сметка, защото земеделците на власт притискат все повече остатъците от Врангеловата армия, докато следващите правителства са ѝ благодарни.

Независимо от посочените забележки, следва да оценим високо монографичния труд на Виктор Ив. Козодой. Неговият поглед е на добър изследовател, видял българската история „отвън”. Чрез проследяването на биографията на Ал. Гучков той ни представя в синтезиран вид политическите отношения в българското общество в периода 1920 - 1923 г., както и влиянието на международните отношения върху външната политика на изолираната победена във войната държава, каквато е България през периода. Авторът поставя за разрешаване много актуални проблеми, преодолявайки успешно инерцията в оценките, която някои историци от недалечното минало са наслоили. Вярвам, че историческата

\footnotetext{
${ }^{12}$ Според В. Козодой през юли 1922 г. тя е едва 10716 души.
} 


\section{Годишник на ФХH, XXXII A}

дискусия, която се открива с тази книга, ще донесе в близко бъдеще много повече яснота по някои важни исторически проблеми.

\section{ИЗПОЛЗВАНА ЛИТЕРАТУРА}

Alekseeva 2005: Alekseeva, S. I. Osnovnye etapy razvitia apparata gosudarstvennogo upravlenia v Rossii. - In: Alekseeva, S. I., O. V. Egorenkova, T. N. Zaharova. Politicheskaya istoria Rossii. Ch. 1. IX - nachalo XX vv. Sankt-Peterburg, s. 182-281 [Алексеева, С. И. Основные этапы развития аппарата государственного управления в России. - В: Алексеева, С. И., О. В. Егоренкова, Т. Н. Захарова. Политическия история Росии. Ч. 1. IX начало Х вв. Санкт-Петербург, с. 182-281].

Balgarskite darzhavni institutsii 1986: Balgarskite darzhavni institutsii 1879 1886. Entsiklopedichen spravochnik (ed. Metodiev, V., L. Stoyanov). Sofia: D-r Petar Beron [Българските държавни институции 1879 - 1886. Енциклопедичен справочник (съст. Методиев, В., Л. Стоянов). София: Д-р Петър Берон].

Georgiev 1989: Georgiev, V. Narodniyat sgovor 1921 - 1923 (kam nachaloto na istoriyata na fashizma v Bulgaria). Sofia: UI „Sv. Kliment Ohridski“ [Георгиев, В. Народният сговор 1921 - 1923 (към началото на историята на фашизма в България). София: УИ „Св. Климент Охридски“].

Georgiev 2014: Georgiev, B. Parlamentarnata opozitsia i vatreshnata politika na balgarskite pravitelstva (avgust 1887 - yanuari 1908). Shumen: UI „Episkop Konstantin Preslavski“" [Георгиев, Б. Парламентарната опозиция и вътрешната политика на българските правителства (август 1887 - януари 1908). Шумен: УИ „Епископ Константин Преславски“].

Georgiev 2018: Georgiev, B. Parlamentarnata opozitsia i promenite na vatreshnopoliticheskoto zakonodatelstvo. Borbata sreshtu lichnia rezhim v Trinadesetoto narodno sabranie. // Istorichesko badeshte, kn. 1-2, s. 167-198 [Георгиев, Б. Парламентарната опозиция и промените на вътрешнополитическото законодателство. Борбата срещу личния режим в Тринадесетото народно събрание. // Историческо бъдеще, 2018, кн. 12, с. 167-198].

Georgiev 2020: Georgiev, B. Parlamentarizam i politikanstvo v Osmoto obiknoveno narodno sabranie. - In: Bulgaria i balgarite: bit, dushevnost, natsionalna identichnost. Materiali ot Shestata natsionalna konferentsia po istoria, arheologia i kulturen turizam „Patuvania kam Bulgaria” - Shumen, 24 - 26. 04. 2018 g. Shumen: UI „Episkop Konstantin Preslavski“, s. 235-254 [Георгиев, Б. Парламентаризъм и политиканство в Осмото обикновено народно събрание. - В: България и българите: бит, душевност, национална идентичност. Материали от Шестата национална конференция по история, археология и културен туризъм „Пътувания 
към България“ - Шумен, 24 - 26. 04. 2018 г. Шумен: УИ „Епископ Константин Преславски“, с. 235-254].

Kozodoy 2004: Kozodoy, V. I. Formirovanie mnogopartiynosti v Sibiri v 1895 - 1996 gg. Novosibirsk [Козодой, В. И. Формирование многопартийности в Сибири в 1895 - 1996 гг. Новосибирск].

Kozodoy 2009: Kozodoy, V. I. Obshtestvennno-politicheskaya zhizny Sibiri: vtoraya polovine 1980 - seredina 90-yh gg. (Istoricheskiy aspekt). Avtoref. dis. ... doktora istor. nauk. Moskva [Козодой, В. И. Общественно-политическая жизнь Сибири: вторая половина 1980 - середина 90-ых гг. (Исторический аспект). Автореф. дис. ... доктора ист. наук. Москва].

Kozodoy 2011: Kozodoy, V. I. Sibirskiy razlom. Obshtestvenno-politicheskaya zhizny Sibiri: 1985 - 1996 gg. Novosibirsk: Paralely [Козодой, В. И. Сибирский разлом. Общественно-политическая жизнь Сибири: 1985 1996 гг. Новосибирск: Параллель].

Kozodoy 2014: Kozodoy, V. I. Guchkov Aleksandr Ivanovich - ot ryadovogo do voennogo ministra. // Gumanitarnye problemy voennogo dela, № 1, Novosibsrsk, s. 121-128 [Козодой, В. И. Гучков Александр Иванович - от рядового до военного министра. // Гуманитарные проблемы военного дела, № 1, Новосибирск, с. 121-128].

Kozodoy 2015: Kozodoy, V. I. Aleksandr Ivanovich Guchkov i Velikaya russkaya revolyutsia. Novosibirsk: Sibirskaya akademiya upravleniya i massovyh kommunikatsiy (institut) [Козодой, В. И. Александр Иванович Гучков и Великая русская революция. Новосибирск: Сибирская академия управления и массовых коммуникаций (институт)].

Kozodoy 2017: Kozodoy, V. I. Novye istochniki k politicheskoy biografii Aleksandra Ivanovicha Guchkova. - In: Velikaya russkaya revolyutsia 1917. 100 let izuchania. Moskva: Institut rossiyskoy istorii RAN [Козодой, В. И. Новые источники к политической биографии Александра Ивановича Гучкова. - Великая российская революция, 1917 : 100 лет изучения. Москва: Институт российской истории РАН].

Kozodoy 2019: Kozodoy, V. I. Byal revansh v stranata na chervenite rozi: Aleksandar Guchkov i darzhavniyat prevrat na 9 yuni 1923 godina v Bulgaria. Veliko Tarnovo: Faber [Козодой, В. И. Бял реванш в страната на червените рози: Александър Гучков и държавният преврат на 9 юни 1923 година в България. Велико Търново: Фабер].

Kozodoy et al. 2018: Kozodoy, V. I. et al. V avangarde molodezhi. Istoria novosibirskogo komsomola (1918 - 1991 gody). Novosibirsk: Nauka [Козодой, В. И. и др. В авангарде молодежи. История Новосибирского комсомола (1918 - 1991 годы). Новосибирск: Наука].

Mitev 1973: Mitev, Y. Fashistkiyat prevrat na deveti yuni 1923 godina i Yunskoto antifashistko vastanie. Sofia: ВКР [Митев, Й. Фашисткият преврат на 


\section{Годишник на ФХH, XXXII $A$}

девети юни 1923 година и Юнското антифашистко въстание. София: БКП].

Naumov 2004: Naumov, G. Aleksandar Tsankov i Andrey Lyapchev v politikata i darzhavnoto upravlenie. Sofia: Balgarski knizhitsi [Наумов, Г. Александър Цанков и Андрей Ляпчев в политиката и държавното управление. София: Български книжици].

Nedev 1984: Nedev, N. Aleksandar Stamboliyski i zagovorat. Sofia: Izdatelstvo BZNS [Недев, Н. Александър Стамболийски и заговорът. София: Издателство БЗНС].

Nedev 2007: Nedev, N. Tri darzhavni prevrata ili Kimon Georgiev i negovoto vreme. Sofia: Siela [Недев, Н. Три държавни преврата или Кимон Георгиев и неговото време. София: Сиела].

Pendzhekova 2007: Pendzhekova, R. Lichnostta i deloto na ekzarh Stefan V balgarskata istoricheska pamet. Smolyan: Otzvuk pres [Пенджекова, P. Личността и делото на екзарх Стефан в българската историческа памет. Смолян: Отзвук прес].

Petrova 1988: Petrova, D. Samostoyatelnoto upravlenie na BZNS 1920 - 1923. Sofia: Nauka i izkustvo [Петрова, Д. Самостоятелното управление на БЗНС, 1920 - 1923. София: Наука и изкуство].

Politicheskie partii Rossii 2000: Politicheskie partii Rossii: istoria i sovremennosty. (ed. Zeveleva, A. I., Yu. P. Sviridenko, V. V. Shepohaeva). Moskva: Rossiyskaya politicheskaya entsiklopediya [Политические партии России: история и современность (ред. Зевелева, А. И., И. Ю. Свириденко, В. В. Шепохаева). Москва: Российская политическая энциклопедия].

Spasov 1977: Spasov, L. Vrangelistite i balgarskata obshtestvenost vav Velikotarnovski okrag prez 1922 g. - In: Trudove na Velikotarnovskiya universitet. Istoricheski fakultet. T. 14, № 3, Veliko Tarnovo: Nauka i izkustvo, s. 94-135 [Спасов, Л. Врангелистите и българската общественост във Великотърновски окръг през 1922 г. - В: Трудове на Великотърновския университет. Исторически факултет. Т. 14, № 3, Велико Търново: Наука и изкуство, с. 94-135].

Spasov 1979 /2/: Spasov, L. Pravitelstvoto na BZNS, balgaro-savetskite otnoshenia i ruskite beloemigranti. // Istoricheski pregled, kn. 2, s. 63-74 [Спасов, Л. Правителството на БЗНС, българо-съветските отношения и руските белоемигранти. // Исторически преглед, кн. 2, с. 63-74].

Spasov 1987: Spasov, L. Sayuzat za vrashtane v rodinata 1922 - 1923 g. // Istoricheski pregled, kn. 11, s. 87-99 [Спасов, Л. Съюзът за връщане в родината 1922 - 1923 г. // Исторически преглед, кн. 11, с. 87-99].

Spasov 1999: Spasov, L. Vrangelovata armiya v Bulgaria 1919 - 1923 g. Sofia: UI „Sv. Kliment Ohridski““ [Спасов, Л. Врангелската армия в България 1919 - 1923 г. София: УИ „Св. Климент Охридски“]. 
Spasov 1979/1/: Spasov, L. Otnoshenieto na politicheskite partii kam prebivavashtite v Bulgaria vrangelistki voyski. - In: Nauchni izsledvania. Velikotarnovski universitet. Veliko Tarnovo, s. 213-231 [Спасов, Л. Отношението на политическите партии към пребиваващите в България врангелски войски. - В: Научни изследвания. Великотьрновски университет. Велико Търново, с. 213-231].

Todorov 2018: Todorov, T. St. Nikola Mushanov - zhivot i obshtestvena deynost. Veliko Tarnovo: Ivis [Тодоров, Т. Ст. Никола Мушанов - живот и обществена дейност. Велико Тьрново: Ивис].

Vasilev 1991: Vasilev, V. Pravitelstvoto na BZNS, VMRO i balgaro-yugoslavskite otnoshenia. Sofia: BAN [Василев, В. Правителството на БЗНС, ВМРО и българо-югославските отношения. София: БАН]. 